\title{
Glacial evolution in the Ayilariju region, Western Himalaya, China: 1980-2011
}

\author{
Zhiguo $\mathrm{Li}^{1,2} \cdot$ Lide Tian $^{2} \cdot$ Haiyan Fang ${ }^{3} \cdot$ Shuhong Zhang ${ }^{4} \cdot$ Jingjing Zhang $^{1} \cdot$ \\ Xuexin $\mathbf{L i}^{1}$
}

Received: 20 May 2015/Accepted: 6 December 2015/Published online: 10 March 2016

(c) Springer-Verlag Berlin Heidelberg 2016

\begin{abstract}
Changes in glacial geometries (extent and surface elevations) in the Ayilariju region of Western Himalaya, China, were investigated using topographical maps and data from the Landsat Thematic Mapper/Enhanced Thematic Mapper Plus, the Satellite Pour l'Observation de la Terre (SPOT4), the Shuttle Radar Topography Mission 4.1 digital elevation model, and geographical information system techniques. The results showed that the total glaciated area decreased from 190.37 to $162.52 \mathrm{~km}^{2}$ (14.6\% of the 1980 glaciated area) from 1980 to 2011. Furthermore, total glacial mass loss of studied region was estimated to be $2.570 \pm 0.327 \mathrm{~km}^{3}$ between 1980 and 2000. Further investigation on meteorological data indicated that increases of temperature and total radiation were the primary causes of accelerated glacial melting. Reduced wind speed and slight decreases in precipitation triggered by weakening of the South Asian summer monsoon due to warming, may also have contributed to glacial shrinkage. The rate of glacial retreat in the studied region is lower than that in the southern Himalayan region, but larger than that in the Karakoram, primarily because Ayilariju glaciers were located on the margin of the Indian monsoon dominated region.
\end{abstract}

Zhiguo Li

lizhiguo999999@163.com

1 Environment and Planning College, Shangqiu Normal University, Shangqiu 476000, China

2 Institute of Tibetan Plateau Research, Chinese Academy of Sciences, Beijing 100101, China

3 Institute of Geographic Sciences and Natural Resources Research, Chinese Academy of Sciences, Beijing 100101, China

4 Life Science College, Shangqiu Normal University, Shangqiu 476000, China
Keywords Glacial evolution · Remote sensing · Western Himalaya $\cdot$ Ayilariju region

\section{Introduction}

The Tibetan Plateau and its surroundings (TPS) contain the largest number of glaciers outside of the Polar Regions (Yao 2008). Glacial changes in the TPS can impact on atmospheric circulation patterns, water cycles, and water resource accessibility for the 1.5 billion people living within the ten countries that surround the region (Immerzeel et al. 2010; Piao et al. 2010; Qiu 2010).

Previous research has indicated that the status of glaciers shows clear spatial heterogeneity across the TPS (Yao et al. 2012; Gardelle et al. 2013; Gardner et al. 2013; Neckel et al. 2014). Glaciers in the Himalaya have undergone intensive shrinkage since the 1970s (Yao et al. 2012), which has been attributed to rising temperatures and decreasing precipitation (Yao et al. 2012; Wiltshire et al. 2014; Yang et al. 2014). However, in contrast to the global trend of declining mountain glaciers, Hewitt (2005) found the Karakoram glaciers to be in a state of expansion (the "Karakoram Anomaly"). The stable or advancing state of the Karakoram glaciers has been confirmed by numerous studies (e.g., Kääb et al. 2012; Yao et al. 2012; Gardelle et al. 2013; Gardner et al. 2013; Neckel et al. 2014), and the phenomenon is considered to result from increased snowfall and cooling at high altitudes (Hewitt 2005; Yang et al. 2014; Wiltshire et al. 2014). Despite adjoining the Karakoram region, glacial mass loss in the Western Himalaya is larger than that of other Himalayan regions (i.e., the eastern and central Himalaya; Gardelle et al. 2013).

The transition zone between the Himalaya and the Karakorum (TZHK) is bordered to the east by 
Depuchangdake, to the west by Jammu-Kashmir and Himachal Pradesh, to the north by Xiongcaigangri, and to the south by Ayilariju. Glaciers in Himachal Pradesh had an overall specific mass balance of -0.7 to $-0.85 \mathrm{~m} \mathrm{a}^{-1}$ (water equivalent) between the fall of 1999 and November 2004 (Berthier et al. 2007). A total deglaciation of $29.1 \mathrm{~km}^{2}$ (i.e., a $26.1 \%$ reduction) was observed from 1966 to 2011 in the Tirungkhad basin (Mir et al. 2014). In the Jammu-Kashmir region, deglaciation at 212 glaciers in the Zanskar Valley resulted in a loss of $57 \mathrm{~km}^{2}$ (i.e., an $8 \%$ reduction); however, this was partially offset by a $42 \mathrm{~km}^{2}$ (or $6 \%$ ) increase in other glaciers. Overall, there was a glacial area decrease of just $15 \mathrm{~km}^{2}$ (or $2 \%$ ) between 1962 and 2001 (Ghosh et al. 2014), of which $6.5 \mathrm{~km}^{2}$ (or $5.6 \%$ ) occurred from 1980 to 2010 in the Shyok Basin (Bajracharya et al. 2015). In Xiongcaigangri and neighboring areas, glaciers have retreated slightly (Brahmbhatt et al. 2015; Li et al. 2015).

Glacial changes in the Ayilariju region have previously been under reported and the differences between the glaciers in Western Himalaya and the Karakoram remain poorly understood. This study focused on glacial changes and their causes in the Ayilariju region from 1980 to 2011. The results provide new insights into the spatial heterogeneity of glacial change in the TZHK and TPS, and provide glacial melt data to improve response measures in populated downstream regions.

\section{Study area}

The Ayilariju region lies in the Western Himalaya, situated on the western Tibetan Plateau (Fig. 1). The climate is driven by the Asian monsoons and westerly cyclones, and most local glaciers have been classified as sub continentaltype (Shi 2008). The Ayilariju glaciers represent the sources of the Sutlej and Shiquan rivers, which are headwaters of the Indus River, and supply fresh water to Shiquanhe city and downstream farmers and herdsmen. Additionally, these glaciers feed many glacial lakes, which when they flood pose a potential threat to the surrounding population. According to the topographical maps $(1: 50,000)$ mapping in 1980, 279 glaciers lie within the study area, comprising a total area of $\sim 190 \mathrm{~km}^{2}$, with an average area per glacier of $\sim 0.68 \mathrm{~km}^{2}$ at the time of mapping.

The mean equilibrium line attitude (ELA) of the glaciers in the Ayilariju region lies at an elevation of $\sim 5800 \mathrm{~m}$ (Shi 2008; Yao et al. 2012). The mean annual air temperature, precipitation, and wind speed from 1961 (start year of observation) to 2011 averaged approximately $0.67{ }^{\circ} \mathrm{C}$, $68.9 \mathrm{~mm}$, and $2.88 \mathrm{~m} / \mathrm{s}$, respectively, at the Shiquanhe meteorological station $\left(32^{\circ} 30^{\prime} \mathrm{N}, 80^{\circ} 08^{\prime} \mathrm{E}, 4278 \mathrm{~m}\right.$ elevation). At the same location, the mean annual total radiation from 1971 (start year of observation) to 2011 approximately to $7640.17 \mathrm{MJ} / \mathrm{m}^{2}$.

\section{Data and methodology}

\section{Remote sensing data}

This study utilized a total of 30 topographical maps $(1: 50,000)$ that were based on aerial photographs acquired by the State Bureau of Surveying and Mapping in 1980 . We digitalized the maps and converted them to the Universal Transverse Mercator (UTM) coordinate system and World Geodetic System 1984 ellipsoidal elevations (WGS84) using kilo-grids and the ENVI/IDL 5.1 software. Root mean square errors (RMSE) were $<2 \mathrm{~m}$ in both the $x$ and $y$ directions. The revised maps were used to generate a digital elevation model (DEM), hereinafter referred to as the 1980 DEM, based on $20 \mathrm{~m}$ interval contours and digitized spot heights. Our seven-parameter datum
Fig. 1 Distribution of glaciers and the location of the Shiquanhe meteorological station: a location of the study area within the Tibetan Plateau and its surroundings (TPS). The dashed line shows the average monsoon moisture limit (after Chen et al. 2008). b Overview of the Ayilariju region and the location of the Shiquanhe meteorological station overlaid on the digital elevation model (DEM)

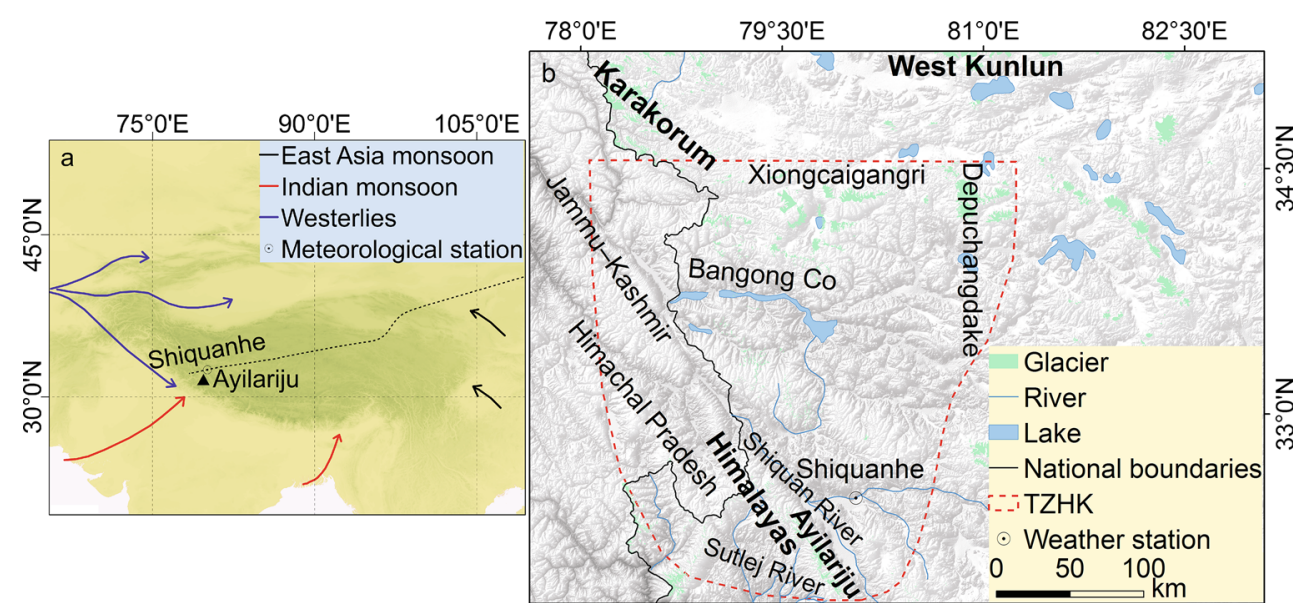


Table 1 Data sources

\begin{tabular}{lllll}
\hline Data source & Acquisition date & Path, row & $\begin{array}{l}\text { Image } \\
\text { resolution }(\mathrm{m})\end{array}$ & DEM error (m) \\
\hline Topographic map & Nov-Dec 1980 & & 5 & 20 \\
Landsat TM & 12 Nov 1989 & Path 145, row 38 & 28.5 & \\
Landsat TM & 15 Nov 1990 & Path 145, row 38 & 28.5 & \\
Landsat TM & 19 Aug 1993 & Path 145, row 38 & 28.5 & \\
Landsat ETM+ & 31 Oct 1999 & Path 145, row 38 & 28.5 & \\
Landsat ETM+ & 02 Nov 2000 & Path 145, row 38 & 28.5 & \\
Landsat ETM+ & 20 Oct 2001 & Path 145, row 38 & 28.5 & \\
Landsat TM & 09 Nov 2011 & Path 145, row 38 & 28.5 & 16 \\
SPOT4 & 03 Oct 2011 & Path 210, row 285 & 20 & \\
SPOT4 & 03 Oct 2011 & Path 210, row 286 & 20 & \\
SRTM & 11-22 Feb 2000 & & 90 & \\
\hline
\end{tabular}

transformation method resulted in errors of $<0.002 \mathrm{~m}$ (Wang et al. 2003). The result of the processing method using the kilo-grids were better than those generated using the seven-parameter datum transformation method. The 1980 DEM yielded various glacial parameters (i.e., area, elevation, mean surface slope, and aspect), which were analyzed with references to glacier numbers, area distributions, and area changes.

This study employed Landsat Thematic Mapper/Enhanced Thematic Mapper Plus (TM/ETM+) and Satellite Pour l'Observation de la Terre (SPOT4) images (Table 1) to extract glacial extent values and to monitor glacial changes. As the 2011 SPOT images did not cover the entire study area, we used 2011 TM images as supplements. Cloud coverage in the 1990 TM, 2000 ETM, and 2011 SPOT images was $<2 \%$, while in the 2011 images it reached $25 \%$. However, cloud masking had little impact on the delineation of glacial outlines because the cloud coverage rarely fell across the glaciers. All of the selected remote sensing images were acquired at the end of the melt season. One or two additional images acquired at almost the same time were used as reference data to help determine seasonal snow cover.

The United States Geological Survey (USGS; http:// glovis.usgs.gov) and Global Land Cover Facility provided the Landsat images. The image data was orthorectified, geo-corrected, and co-registered using the previously processed topographic maps (using an RMSE value of $<14.25 \mathrm{~m}$ in both the $x$ and $y$ directions, with 20 points). The processed topographical maps and 1980 DEM orthorectified the two SPOT images to the WGS84 UTM datum using an RMSE value of $<10 \mathrm{~m}$ in both the $x$ and $y$ directions (with 16 points). We used manual digitization to delineate the boundaries of the glaciers following the method of Raup et al. (2007), which provided the best tool for extracting reliable information from satellite images.

The 1980 DEM and Shuttle Radar Topography Mission (SRTM) data were used to calculate changes in glacial volume. The SRTM 4.1, whose study area data gaps had already been processed (Reuter et al. 2007), was selected and obtained from the Consultative Group on International Agricultural Research-Consortium for Spatial Information (CSI-CGIA; http://srtm.csi.cgiar.org/). The SRTM DEM was geo-corrected and co-registered using the 1980 DEM, with a RMSE of $<45 \mathrm{~m}$ in both the $x$ and $y$ directions, and re-sampled to a $20 \mathrm{~m}$ interval (SRTMDEMP). We calculated glacial ice volume changes between the 1980 DEM and the SRTMDEMP data by multiplying the mean value of the surface elevation change and the glacial surface area in 1980. When converting volume change into a mass change, we assumed an ice density of $900 \mathrm{~kg} \mathrm{~m}^{-3}$.

\section{Meteorological data}

No meteorological monitoring stations were operated within the study area during our study period, with Shiquanhe the nearest station. The distances between the Shiquanhe station and the Ayilariju glaciers ranged from 38 to $76 \mathrm{~km}$. Meteorological data from Shiquanhe were downloaded from the China Meteorological Data Sharing Service System (http:// cdc.cma.gov.cn) and were used to analyze variations in climate and to discern reasons for glacial changes between 1980 and 2011. Temperature, precipitation, total radiation, and wind speed were selected for analysis. Evaporation data was not used owing to data loss in many months. Months with mean temperatures of $\geq 0{ }^{\circ} \mathrm{C}$ were classified as the warm season (from April to October), while those with means temperatures of $<0{ }^{\circ} \mathrm{C}$ were classified as the cold season (from November to March).

\section{Precision evaluation}

Glacial changes in the Ayilariju region occurred mainly at glacier termini; therefore, the error estimation method for the image co-registration mirrored the approach used in 
previous studies (Ye et al. 2006; Cao et al. 2014; Wang et al. 2014). The errors extracted from multi-temporal satellite images resulted mainly from (1) sensor resolution, (2) co-registration errors, and (3) boundary delineations. The first two error types were evaluated using a remote sensing uncertainty evaluation formula (Ye et al. 2006), in which the linear uncertainty was expressed as:

$U_{L}=\sqrt{\sum \lambda^{2}}+\sqrt{\sum \sigma^{2}}$

where $U_{L}$ is the measurement uncertainty of the glacier terminus in the study area, $\lambda$ is the original pixel resolution of each image, and $\sigma$ is the co-registration error of each image to the topographic map of 1980 .

The area uncertainty between the multiple remote sensing data can be expressed as:

$U_{A}=\sum \lambda^{2} * \frac{2 * U_{L}}{\sqrt{\sum \lambda^{2}}}+\sum \sigma^{2}$

where $U_{A}$ denotes the measurement uncertainty of the glacier area, and $U_{L}$ gives the linear uncertainty. Equations (1) and (2) were used to calculate the uncertainties in the glacier termini positions and areas measured in this study (Table 2).

Glacial delineation errors result mainly from the experience of the operator, in particular when classifying shadowed areas as perennial or seasonal snow (Xiang et al. 2014). The changes in glacial area between the 2011 images and the 1980 topographic maps were delineated by two additional independent colleagues in order to estimate delineation error and the differences between the different operators were within $3 \%$. Based on tests and analyses, the differences determined in glacial area caused by image quality, which can be affected by seasonal snow and shadow, was $<2 \%$.

The vertical biases between the 1980 DEM and SRTMDEMP in non-glaciated areas, which have probably not changed in 20 years, was evaluated by comparing 360 elevation check points with the corresponding height values for the same locations in the two DEMs. The points were selected with the help of Google Earth. None were located in places where landslides, mudslides, significant erosion, and vegetation cover have occurred. The mean height deviation of SRTMDEMP minus the 1980 DEM was $-1.72 \mathrm{~m}$, the maximum height deviations were $16 \mathrm{~m}$ and $-21 \mathrm{~m}$, and the residual RMSE was $9.45 \mathrm{~m}$.

\section{Results}

\section{Overall changes in the glaciated area}

This study focused on the distribution and change in the clean ice of the glaciers in the Ayilariju region. Debris-mantled parts of some glaciers have not been reconstructed because they were difficult to discern under the thick debris. The total glaciated area in the study region decreased from $190.37 \mathrm{~km}^{2}$ in 1980 to $162.52 \mathrm{~km}^{2}$ in 2011, corresponding to a total ice loss of $27.85 \mathrm{~km}^{2}$ (Table 3). A mean observed decrease in glacial area of $0.5 \%$ per year indicates rapid glacial retreat. Six small glaciers, with areas of $0.03-0.15 \mathrm{~km}^{2}$, disappeared between 1980 and 2011. Eleven glaciers with areas of $0.13-2.24 \mathrm{~km}^{2}$ in 1980 each became separated into two glaciers, with areas of $0.14-1.59 \mathrm{~km}^{2}$. Two glaciers became separated into three glaciers apiece. The mean areal shrinkage rate varied over different periods, with relatively larger values between 1990 and $2000\left(0.8 \% \mathrm{a}^{-1}\right)$. The most rapid glacial retreats between 1990 and 2000 appear to have been related to steep or very flat portions of some thin glaciers, which were prone to shrinkage. Five of the aforementioned six disappeared glaciers vanished between 1990 and 2000, while 10 of the aforementioned 14 (the 11 plus 2) separated glaciers split between 1990 and 2000.
Table 2 Temporal differences in uncertainty

\begin{tabular}{llll}
\hline Periods & Data & Linear uncertainty $(\mathrm{m})$ & Area uncertainty $\left(\mathrm{km}^{2}\right)$ \\
\hline 1980-1990 & Topographic map-Landsat TM & 32.97 & 0.002 \\
$1990-2000$ & Landsat TM-Landsat ETM+ & 45.64 & 0.004 \\
$2000-2011$ & Landsat ETM+ to SPOT & 39.74 & 0.003 \\
$2000-2011$ & Landsat ETM+ to Landsat TM & 45.64 & 0.004 \\
\hline
\end{tabular}

Table 3 Variations in the glaciated area of Ayilariju region (1980-2011)

\begin{tabular}{lllllll}
\hline Date & Area $\left(\mathrm{km}^{2}\right)$ & Period & Area change $\left(\mathrm{km}^{2}\right)$ & Mean rate $\left(\mathrm{km}^{2} \mathrm{a}^{-1}\right)$ & Area change $(\%)$ & Mean rate \\
\hline 1980 & 190.37 & & & & -3.0 & -0.3 \\
1990 & 184.72 & $1980-1990$ & -5.64 & -0.56 & -8.3 & -0.8 \\
2000 & 169.01 & $1990-2000$ & -15.71 & -1.57 & -0.65 & -0.3 \\
2011 & 162.52 & $2000-2011$ & -6.49 & -0.90 & -0.5 \\
Total & & $1980-2011$ & -27.85 & & & -14.6 \\
\hline
\end{tabular}


Impact of size and topography on glacial areal distribution and temporal variation

Size and topographic features (e.g., elevation, slope, and aspect) vary from glacier to glacier, and may affect their rate of change. The 279 glaciers of the Ayilariju region can be classified into six groups based on their 1980 areas. Small glaciers make up the largest proportion of the total number (Fig. 2), with 231 having an area of $<1 \mathrm{~km}^{2}$ (in 1980), which accounted for $82.8 \%$ of the total number of glaciers, $33.4 \%$ of the total area, and $84.5 \%$ of the total decrease in area over the study period (Fig. 2). Forty-eight glaciers had areas of $>1$ and $<5 \mathrm{~km}^{2}$, accounting for $15.1 \%$ of the total number of glaciers, but $42.8 \%$ of the total area and $12.7 \%$ of the total decrease in area during the study period. Only six glaciers had areas of greater than $5 \mathrm{~km}^{2}$, accounting for $7.6 \%$ of the total of number of glaciers, but $55.7 \%$ of the total area and $1.4 \%$ of the total area decrease.

Glacial area distribution was divided into six 200-m elevation intervals and the area change over time was analyzed based on these elevation intervals (Fig. 3). Glaciated

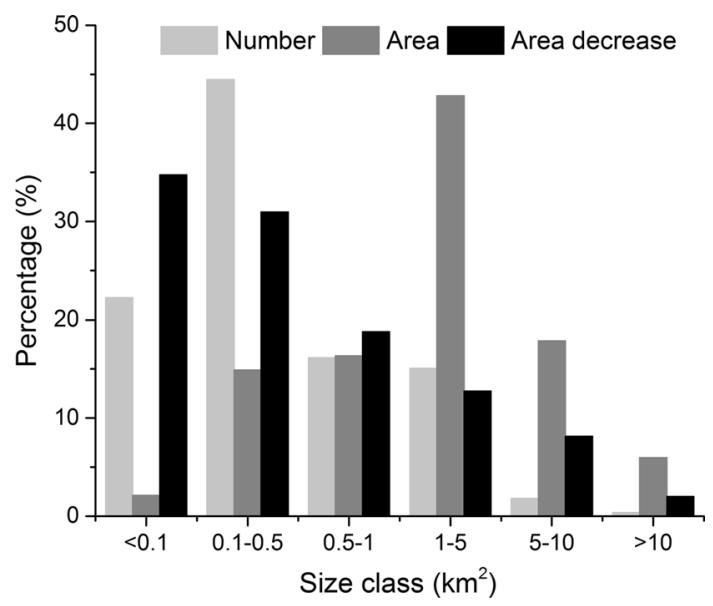

Fig. 2 Percentage $(\%)$ change in the glacier number, area distribution, and area decrease as a function of size $\left(\mathrm{km}^{2}\right)$

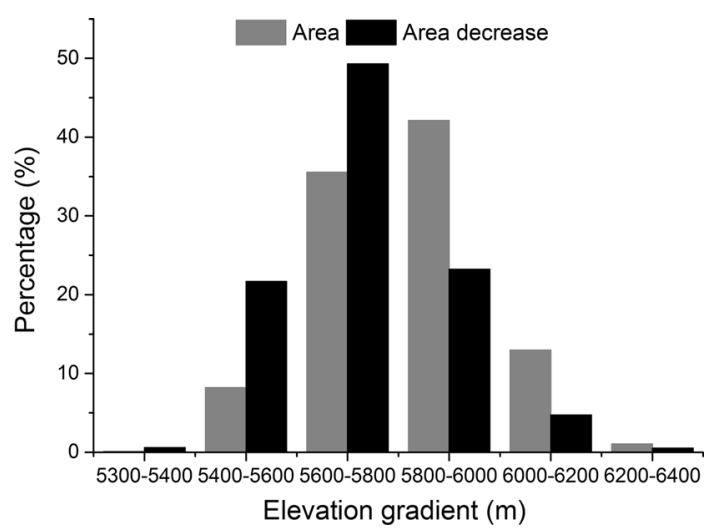

Fig. 3 Percentage (\%) change in glaciated area and area decrease as a function of elevation $(\mathrm{m})$ areas increased up to an elevation of 5600-5800 m, but then decreased at higher elevations. Most of the glacial area $\left(188.13 \mathrm{~km}^{2}\right)$ fell within three elevation intervals, between 5400 and $6200 \mathrm{~m}$, which accounted for $98.8 \%$ of the total area. The glacial area in the other three intervals covered just $2.23 \mathrm{~km}^{2}$, accounting for $1.17 \%$ of the total area. This distribution of glacial area reflected the combined effects of precipitation and terrain on glacier development. The glaciers lost $27.54 \mathrm{~km}^{2}$ of area $(98.9 \%$ of the total glacier area lost) from 1980 to 2011, with most of the loss occurring at elevations between 5400 and $6200 \mathrm{~m}$. Glaciated areas at elevations higher than $6357 \mathrm{~m}$ showed no shrinkage. Excluding the six glaciers that disappeared completely, the mean change for the lowest, highest, and mean elevations from 1980 to 2011 were $34.47,-4.63$ and $12.66 \mathrm{~m}$, respectively. Changes at the lowest and highest elevations imply that these glaciers shrunk into the middle glacier groups, while the mean elevation rise indicates that glaciers tended to retreat to higher elevations.

The number, area, and percent decrease in glaciers were compared for eight slope angles (Fig. 4). The five intervals between $10^{\circ}$ and $35^{\circ}$ had a combined area of $180.11 \mathrm{~km}^{2}$, containing a total of 264 glaciers $(94.6 \%$ of the total number) and accounting for $94.61 \%$ of the total area. The other three intervals contained a total area of $10.26 \mathrm{~km}^{2}$, contained 15 glaciers (5.4\% of the total), and accounted for $5.4 \%$ of the total area. Glaciers on all slopes showed a decrease in area between 1980 and 2011 (Fig. 4). The largest area change occurred for slopes between $10^{\circ}$ and $35^{\circ}$, with a combined area reduction of $27.26 \mathrm{~km}^{2}$ (accounting for $97.9 \%$ of the total decrease). The area decreases for each slope interval (excepting $10^{\circ}-15^{\circ}$ ) were between 14.2 and $48.9 \%$. The largest percentage area decrease occurred for the lowest slope class $\left(5^{\circ}-10^{\circ}\right)$; however, this somewhat reflects the small sample set, with only three glaciers in the $5^{\circ}-10^{\circ}$ slope class, of which one disappeared before 2000 .

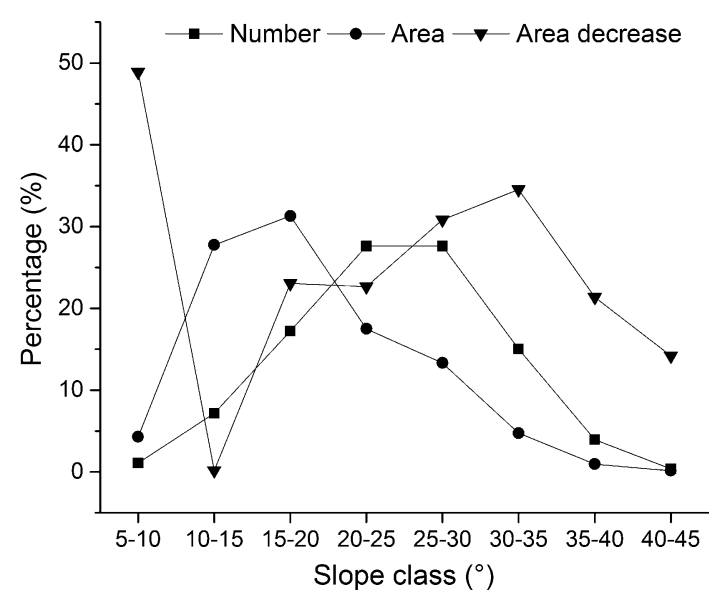

Fig. 4 Percentage (\%) change in the number of glaciers, glacial area, and area decrease as a function of slope $\left(^{\circ}\right)$ 
Tennant et al. (2012) and Racoviteanu et al. (2015) found that the steeper the glacier, the larger the area loss. However, no clear relationship was found between glacial area loss and slope angle in the Ayilariju region, indicating that the collective affects of size, elevation, slope, and aspect are complex. Furthermore, other attributes related to glacier type and the source of nourishment (i.e., outlet, cirque, avalanche-fed, and debris-covered glaciers) may also impact on glacial change (Tennant et al. 2012).

The distributions of glacial areas and area decrease were analyzed as a function of aspect (i.e., the directions they face), at $45^{\circ}$ intervals (Fig. 5). In 1980, the numbers

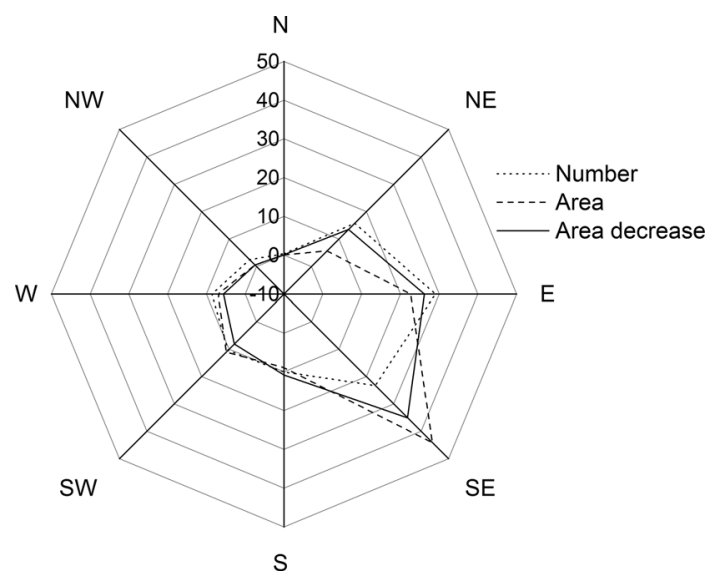

Fig. 5 Percentage $(\%)$ of glaciers as a function of aspect, glacial area $\left(\mathrm{km}^{2}\right)$, and area decrease $\left(\mathrm{km}^{2}\right)$ of glaciers facing northeast, east, southeast, south, and southwest each accounted for $>10 \%$ of the total, in combination representing over $88.5 \%$ of the total number of glaciers. In contrast, the numbers facing west, northwest, and north each accounted for $<10 \%$ of the total, in combination representing just $11.5 \%$ of the total number of glaciers. The predominant aspects were east, southeast, and southwest, which together accounted for $77.8 \%$ of total glaciated area. The number and area distribution of glaciers was primarily controlled by local climate and topographic effects. Glaciers with all aspects retreated between 1980 and 2011; however, the rate of retreat varied from 14.0 to $39.9 \%$. Absolute area change for glaciers facing northeast, east, southeast, south, and southwest, was $26.10 \mathrm{~km}^{2}$, which accounts for $93.7 \%$ of the total reduction in the glaciated area. The largest percentage area decreases $(35.1 \%$ in total) occurred for glaciers facing southeast.

\section{Changes in ice volume and glacier surface elevation}

The change in mean surface elevation of the Ayilariju region between 1980 and 2000 was $-13.5 \mathrm{~m}$, yielding a rate of decrease of $0.675 \mathrm{~m} \mathrm{a}^{-1}$ (Fig. 6). The surface elevation ranged from -240.28 to $182.85 \mathrm{~m}$, with decreases primarily occurring at glacier termini, and increases primarily occurring in glacier interiors or at high elevations. Based on our analyses, we estimated that the total glacial
Fig. 6 Changes in the surface elevation $(\mathrm{m})$ of glaciers in the Ayilariju region between 1980 and 2000

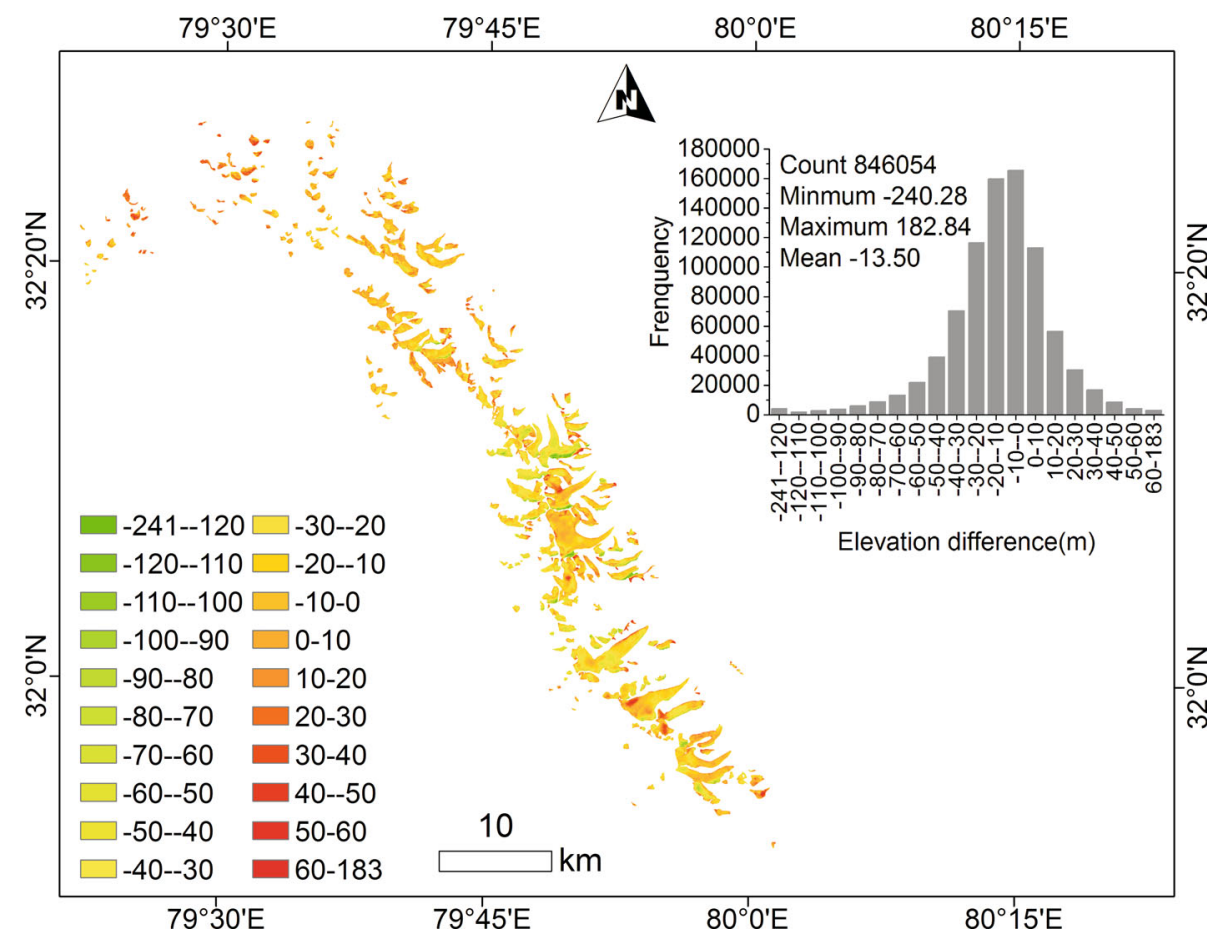


mass loss in the Ayilariju region was $2.570 \pm 0.327 \mathrm{~km}^{3}$ between 1980 and 2000.

\section{Discussion}

The mean monthly temperatures in the warm (ATWS) and cold (ATCS) seasons of 2011 were 1.50 and $1.84{ }^{\circ} \mathrm{C}$ higher than those in 1980, respectively (Fig. 7a). The increasing warm season monthly temperatures could accelerate glacial melting, while the increase in monthly temperatures in both the warm and cold seasons could shorten the shift, during which (i.e., when glaciers transition from accumulation to melt) and lengthen the ablation period (Liu et al. 1999; Zeng et al. 2013). Ice temperature during the cold season are high; therefore, when the ablation season starts, glaciers will consume less of their ablation energy reserves in lower temperature years, which will increase glacial melt (Zeng et al. 2013) and accelerate glacial shrinkage.

The mean monthly precipitation values during the warm (APWS) and cold (ATPS) seasons of 1980-2011 showed only minor changes (Fig. 7b). In 2011, the warm and cold season precipitation values were 1.79 and $0.4 \mathrm{~mm}$ lower than in 1980, respectively (i.e., the change amplitude was not large). While sub-polar continental-type glaciers can gain mass in both warm and cold seasons, a decrease in precipitation can also reduce accumulation in all seasons.

In 2011, the mean monthly total radiation values during the warm (ARWS) and cold (ARCS) seasons were 1207.16 and $689.22 \mathrm{MJ} / \mathrm{m}^{2}$ higher than in 1980 , respectively (Fig. 7c). Evaporation (sublimation) caused by radiation is one of the main forms of ablation on sub-polar continentaltype glaciers (Zhang et al. 1996). These radiation increases can accelerate glacial shrinkage.

In 2011, the mean monthly wind speed values in the warm (AWSWS) and cold (AWSCS) seasons were 0.69 and $0.46 \mathrm{~m} / \mathrm{s}$ lower than in 1980, respectively (Fig. 7d). Wind speed represents a potentially important predictor for annual mass-balance (Mölg et al. 2014), and so reduced wind speed may cause glacial change.

From 1980 to 1990,1990 to 2000, and 2000 to 2011, the coefficients of multiple correlations $\left(R^{2}\right)$ between glacial
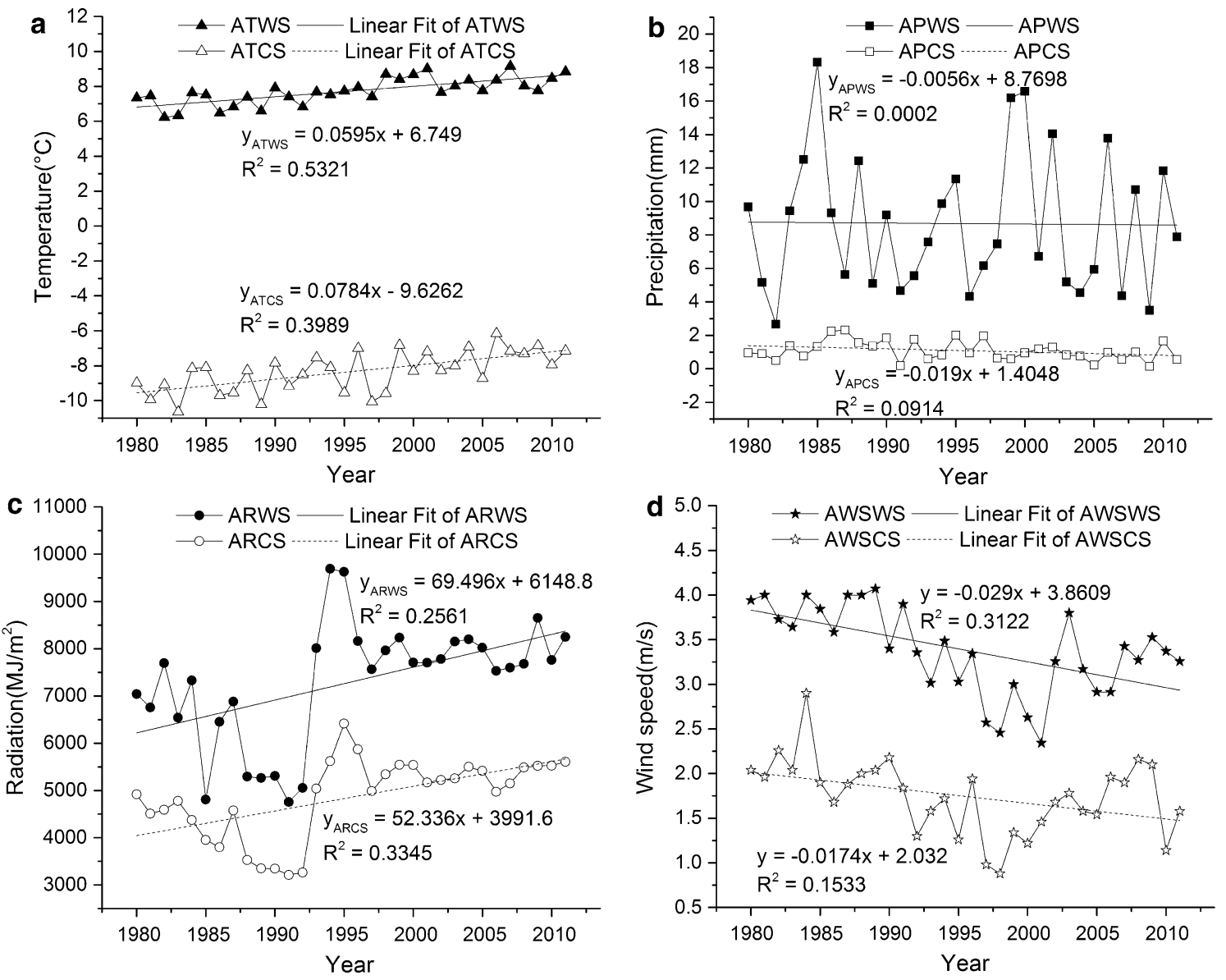

Fig. 7 Changes in mean monthly temperature $\left({ }^{\circ} \mathrm{C}\right)$, precipitation $(\mathrm{mm})$, radiation $\left(\mathrm{MJ} / \mathrm{m}^{2}\right)$, and wind speed $(\mathrm{m} / \mathrm{s})$ during both the warm and cold seasons from 1980 to 2011 
Table 4 Correlation between rate of glacial retreat and meteorological data

\begin{tabular}{llll}
\hline & Correlation formula & $R$ & $R^{2}$ \\
\hline Mean monthly wind speed (cold season): AWSCS & $Y=-1.463 x+3.464$ & 0.883 & 0.78 \\
Mean monthly wind speed (warm season): AWSWS & $Y=-0.947 x+4.123$ & 0.689 & 0.475 \\
Mean monthly radiation (warm season): ARWS & $Y=0.000 x-1.117$ & 0.439 & 0.192 \\
Mean monthly radiation (cold season): ARCS & $Y=0.000 x-0.729$ & 0.381 & 0.145 \\
Mean monthly precipitation (warm season): APWS & $Y=0.372 x-2.304$ & 0.37 & 0.137 \\
Mean monthly temperature (warm season): ATWS & $Y=0.190 x-0.543$ & 0.213 & 0.046 \\
Mean monthly precipitation (cold season): APCS & $Y=-0.400 x+1.363$ & 0.195 & 0.038 \\
Mean monthly temperature (cold season): ATCS & $Y=-0.028 x+0.69$ & 0.044 & 0.002 \\
\hline
\end{tabular}

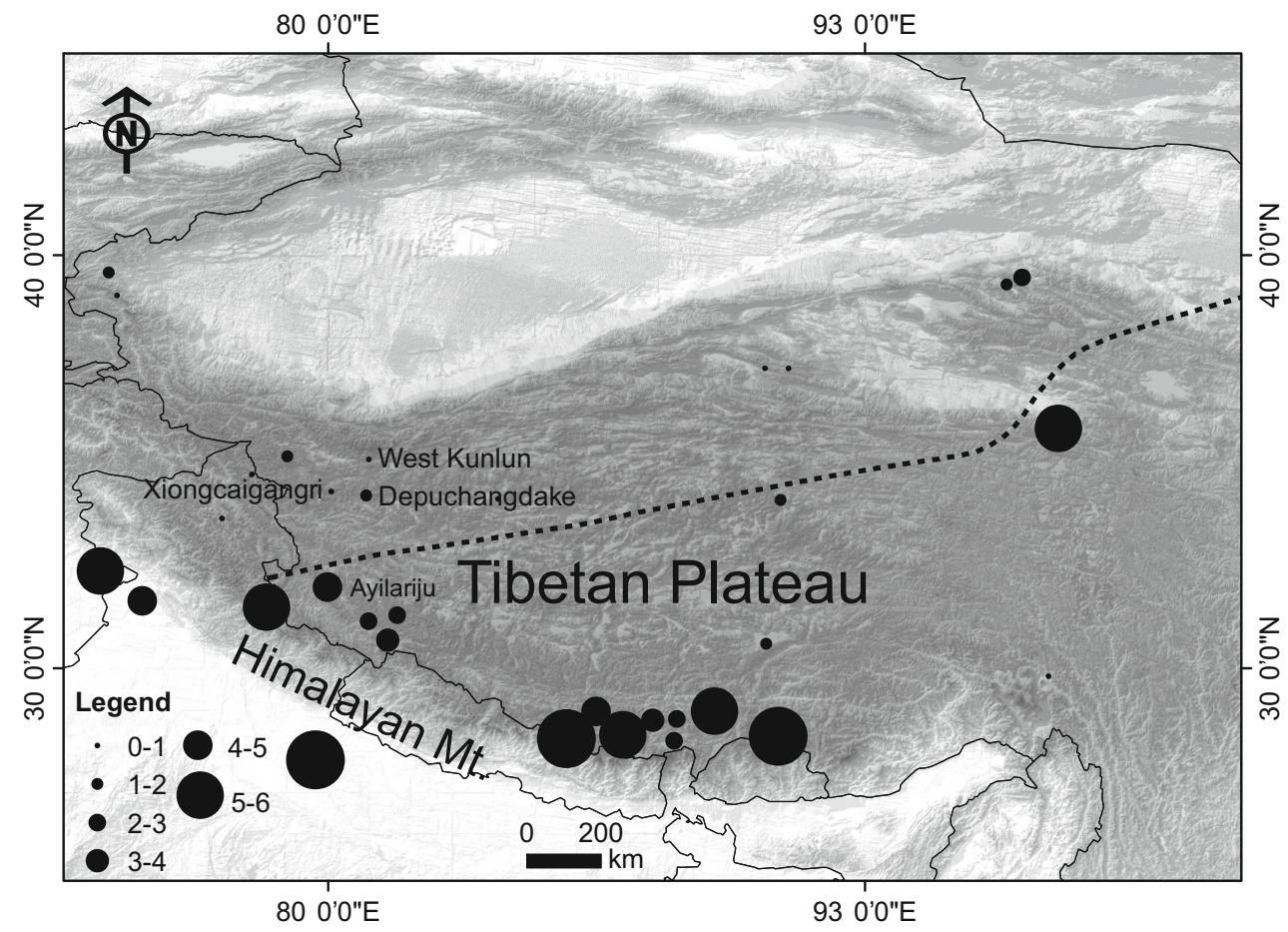

Fig. 8 Glacial retreat rates in the TPS $\left(10 \% \mathrm{a}^{-1}\right)$, modified from $\mathrm{Li}$ et al. (2015). The dashed line shows the mean monsoon margin, which fluctuates between seasons and years retreat and the different meteorological variables were 0.78 (AWSCS), 0.475 (AWSWS), 0.192 (ARWS), 0.145 (ARCS), 0.137 (APWS), 0.046 (ATWS), 0.038 (APCS), and 0.002 (ATCS; Table 4). For glaciers in monsoondominated areas, the $300-\mathrm{hPa}$ wind speed experienced during the onset of the Indian summer monsoon over the Tibetan Plateau's central region represents an excellent predictor for annual mass-balance (Mölg et al. 2014). The Ayilariju glaciers are located at the monsoon limit, and so wind speed in both the warm and cold seasons shows high correlation with glacial retreat; therefore, both may be indicative of annual mass balance. The $R^{2}$ value between AWSCS and ATCS was 0.009, and that between AWSWS and ATWS was 0.343; therefore, rising temperatures showed a clear correlation with decreasing wind speed, likely suggesting a causal relationship. The positive correlation between wind speed and total radiation during both the warm $\left(R^{2}=0.221\right)$ and cold $\left(R^{2}=0.120\right)$ seasons suggests that total radiation represents another influencing factor. The positive correlation between temperature and total radiation during both the warm $\left(R^{2}=0.178\right)$ and cold $\left(R^{2}=0.120\right)$ season suggests that total radiation contributed to rising temperature. However, these positive correlations between temperature and total radiation were comparatively low, which may imply that total radiation represented a less critical driving factor, with global warming the main cause.

Warming across the Tibetan Plateau (TP) and Indian Ocean may weaken latitudinal gradients of both regional temperature and surface pressure; thus, altering regional atmospheric circulation and accounting in part for the observed decline in wind speed (Yang et al. 2012; You et al. 2014; Roxy et al. 2015). In turn, this may suggest a weakening of the South Asian summer monsoon and a corresponding reduction in precipitation. The decreasing trends in APWS and APCS concurred with the reduced 
precipitation trend across the Indian subcontinent (Roxy et al. 2015). Our results suggest that warming (i.e., increasing temperature and total radiation) resulting from a weakened South Asian summer monsoon represents the main cause of glacial retreat, decreasing precipitation and decreasing wind speed. These reductions in wind speed and precipitation also contribute to glacier shrinkage.

Our results show that glacial retreat was fastest in areas dominated by the Indian summer monsoon, while slow retreat was observed in westerly wind dominated areas (Fig. 8), which is consistent with previous findings (Yao et al. 2012). The weakening Indian monsoon, strengthened westerlies (Yao et al. 2012), and the interplay between both circulation systems governs the mass balance. The velocity of areal retreat in Ayilariju (in the northern part of Western Himalaya) exceeded that in adjoining Xiongcaigangri (southern Karakorum; Li et al. 2015) and in West Kunlun (Li et al. 2013) by approximately 15 times. Ayilariju lies on the southern border of the TZHK, which represents the transition zone between areas dominated by the Indian monsoon and those dominated by the westerlies. We suggest that glacial retreat in the Ayilariju region is less than that of the southern Himalayan glaciers, and larger than that of the Karakoram glaciers, mainly owing to their position on this climate margin. Furthermore, the Ayilariju and Xiongcaigangri glaciers have mean sizes of 0.68 and $1.18 \mathrm{~km}^{2}$, and mean elevations of 5826.2 and $6054.4 \mathrm{~m}$, respectively. We suggest that the rapid glacial retreat in Ayilariju may also result from these differences. Finally, proximity to the sources of anthropogenic emissions (e.g., dust and black carbon; Xu et al. 2009), may also impact on Himalaya glaciers, thereby affecting the regional water cycle.

The results of our study into glacial elevation variations in the Ayilariju region agree with those of other studies on the Himalaya. We observed a total elevation change rate of $0.675 \mathrm{~m} \mathrm{a}^{-1}$, as compared to -2 to $+1 \mathrm{~m} \mathrm{a}^{-1}$ (Gardner et al. 2013), -0.30 to $-0.15 \mathrm{~m} \mathrm{a}^{-1}$ (Kääb et al. 2012), $-0.37 \pm 0.25 \mathrm{~m} \mathrm{a}^{-1} \quad$ (Neckel et al. 2014), and $-0.45 \pm 0.14 \mathrm{~m} \mathrm{a}^{-1}$ (Gardelle et al. 2013). However, we did not address the potential penetration of SRTM, which may have affected the results.

\section{Conclusions}

This study used topographic maps, Landsat TM/ETM+, SPOT4, SRTM4 DEM, and Glas/ICESat remote sensing data to determine and interpret glacial changes in the Western Himalaya. The investigation on 279 glaciers showed significant changes in glacial area, ice volume, and surface elevation between 1980 and 2011 .
The total glaciated area decreased from $190.37 \mathrm{~km}^{2}$ in 1980 to $162.52 \mathrm{~km}^{2}$ in 2011 , amounting to an area loss of $14.6 \%$ at a loss rate of $0.5 \% \mathrm{a}^{-1}$. The inverse relationship between glacial area and the rate of change indicates that small glaciers receded at rapid speed. Spatially, the largest amount of glacial melting $\left(27.54 \mathrm{~km}^{2}\right)$ occurred between elevations of 5400 and $6200 \mathrm{~m}$, accounting for almost $99 \%$ of the total glacial retreat in the study area. The decreases in glacial area as a function of slope were between 14.2 and $48.9 \%$ for all slope intervals except $10^{\circ}-$ $15^{\circ}$. The greatest decreases in glacial area occurred for glaciers facing northeast, east, southeast, south, and southwest, with a combined reduction in area of $26.1 \mathrm{~km}^{2}$, or nearly $94 \%$ of the total reduction. The mean surface elevation change in the Ayilariju region was $-13.5 \mathrm{~m}$, with a rate of decrease of $0.675 \mathrm{~m} \mathrm{a}^{-1}$ and a total glacial mass loss of $2.570 \pm 0.327 \mathrm{~km}^{3}$ between 1980 and 2000 .

The results suggested that increasing temperatures and total radiation were the primary cause of accelerated glacial melting. Next, reduced wind speed and a slight decrease in precipitation reduced by weakening of the South Asian summer monsoon also had some contributions.

Our primary observations results on the Ayilariju glaciers relied on remote sensing images, which is a little tentative and additional fieldwork is need to be conducted to confirm our tentative conclusions. Additionally, longterm observations, including on high-resolution remotesensing data, meteorological data from different elevations within the glaciated area, and more ground-based observations, are required before we can gain a full understanding of glacial shrinkage in this region.

Acknowledgments This work was supported by the National Natural Science Foundation of China (Grant Nos. 41101072, 41530748, 41025002, 31100369). Landsat images, SRTM DEMS were provided by the USGS. Meteorological data from the Shiquanhe station were kindly provided by the China Meteorological Data Sharing Service System.

\section{References}

Bajracharya SR, Maharjan SB, Shrestha F, Guo W, Liu SY, Immerzeel W, Shrestha B (2015) The glaciers of the Hindu Kush Himalayas: current status and observed changes from the 1980s to 2010. Int J Water Resour Dev 31(2):161-173

Berthier E, Arnaud Y, Kumar R, Ahmad S, Wagnon P, Chevallier P (2007) Remote sensing estimates of glacier mass balances in the Himachal Pradesh (Western Himalaya, India). Remote Sens Environ 108:327-338

Brahmbhatt RM, Bahuguna IM, Rathore BP, Singh SK, Rajawat AS, Shah RD, Kargel JS (2015) Satellite monitoring of glaciers in the Karakoram from 1977 to 2013: an overall almost stable population of dynamic glaciers. Cryosphere Discuss 9:1555-1592

Cao B, Pan BT, Wang J, Shangguan DH, Wen ZL, Qi WT, Cui H, Lu YY (2014) Changes in the glacier extent and surface elevation 
along the Ningchan and Shuiguan river source, eastern Qilian Mountains, China. Quat Res 81(3):531-537

Chen F, Yu Z, Yang M, Ito E, Wang S, Madsen DB, Huang X, Zhao Y, Sato T, John B, Birks H, Boomer I, Chen J, An C, Wünnemann B (2008) Holocene moisture evolution in arid central Asia and its out-of-phase relationship with Asian monsoon history. Quat Sci Rev 27:351-364

Gardelle J, Berthier E, Arnaud Y, Kääb A (2013) Region-wide glacier mass balances over the Pamir-Karakoram-Himalaya during 1999-2011. Cryosphere 7(4):1263-1286

Gardner AS, Moholdt G, Cogley JG, Bert Wouters, Arendt AA, Wahr J, Berthier E, Hock R, Pfeffer WT, Kaser G, Ligtenberg SRM, Bolch T, Sharp MJ, Hagen JO, van den Broeke MR, Paul F (2013) A reconciled estimate of glacier contributions to sea level rise: 2003 to 2009. Science 340(6134):852-857

Ghosh S, Pandey AC, Nathawat MS, Bahuguna IM, Ajai (2014) Contrasting signals of glacier changes in Zanskar valley, Jammu \& Kashmir, India using remote sensing and GIS. J Indian Soc Remote 42(4):817-827

Hewitt K (2005) The Karakoram anomaly? Glacier expansion and the 'elevation effect', Karakoram Himalaya. Mt Res Dev 25(4):332-340

Immerzeel WW, van Beek LPH, Bierkens MFP (2010) Climate change will affect the Asian water towers. Science 328(5984):1382-1385

Kääb A, Berthier E, Nuth C, Gardelle J, Arnaud Y (2012) Contrasting patterns of early twenty-first-century glacier mass change in the Himalayas. Nature 488(7412):495-498

Li CX, Yang TB, Tian HZ (2013) Variation of West Kunlun Mountains glacier during 1990-2011. Prog Geog 32(4):548-559 (in Chinese with English abstract)

Li ZG, Fang HY, Tian LD, Dai YF, Zong JB (2015) Changes in the glacier extent and surface elevation in Xiongcaigangri region, Southern Karakoram Mountains, China. Quat Int 371:67-75

Liu SY, Wang NL, Ding YJ, Xie ZC (1999) On the characteristic of glacier fluctuations during the last 30 years in Urumqi River Basin and the estimation of temperature rise in the high mountain area. Adv Earth Sci 14(3):279-285 (in Chinese with English abstract)

Mir RA, Jainb SK, Sarafa AK, Goswamic A (2014) Glacier changes using satellite data and effect of climate in Tirungkhad basin located in western Himalaya. Geocarto Int 29(3):293-313

Mölg T, Maussion F, Scherer D (2014) Mid-latitude westerlies as a driver of glacier variability in monsoonal High Asia. Nat Clim Change 4(4):68-73

Neckel N, Kropáček J, Bolch T, Hochschild V (2014) Glacier mass changes on the Tibetan Plateau 2003-2009 derived from ICESat laser altimetry measurements. Environ Res Lett 9(1):014009

Piao S, Ciais P, Huang Y, Shen ZH, Peng SS, Li JS, Zhou LP, Liu HY, Ma YC, Ding YH, Friedlingstein P, Liu CZ, Tan K, Yu YQ, Zhang TY, Fang JY (2010) The impacts of climate change on water resources and agriculture in China. Nature 467(7311):43-51

Qiu J (2010) Measuring the meltdown. Nature 468(7321):141-142

Racoviteanu AE, Arnaud Y, Williams MW, Manley WF (2015) Spatial patterns in glacier characteristics and area changes from 1962 to 2006 in the Kanchenjunga-Sikkim area, eastern Himalaya. Cryosphere 9:505-523

Raup BH, Kääb A, Kargel JS, Bishop MP, Hamilton G, Lee E, Paul F, Rau F, Soltesz D, Khalsa SJS, Beedle M, Helm C (2007) Remote sensing and GIS technology in the Global Land Ice Measurements from Space Project. Comput Geosci UK 33(1):104-125

Reuter HI, Nelson A, Jarvis A (2007) An evaluation of void filling interpolation methods for SRTM data. Int J Geogr Inf Sci 21(9):983-1008

Roxy MK, Ritika K, Terray P, Murtugudde R, Ashok K, Goswami BN (2015) Drying of Indian subcontinent by rapid Indian Ocean warming and a weakening land-sea thermal gradient. Nat Commun 6:7423

Shi YF (2008) Concise glacier inventory of China. Shanghai Popular Science Press, Shanghai

Tennant C, Menounos B, Wheate R, Clague JJ (2012) Area change of glaciers in the Canadian Rocky Mountains, 1919 to 2006. Cryosphere 6:1541-1552

Wang J, Wang J, Lu C (2003) Problem of coordinate transformation between WGS-84 and BEIJING 54. J Geodesy Geodyn 23:70-73 (in Chinese with English abstract)

Wang L, Li ZQ, Wang FT, Edwards R (2014) Glacier shrinkage in the Ebinur lake basin, Tien Shan, China, during the past 40 years. J Glaciol 60(220):245-254

Wiltshire A J (2014) Climate change implications for the glaciers of the Hindu Kush, Karakoram and Himalayan region. Cryosphere 8(3):941-958

Xiang Y, Gao Y, Yao TD (2014) Glacier change in the Poiqu River basin inferred from Landsat data from 1975 to 2010. Quat Int 349(28):392-401

Xu BQ, Cao JJ, Hansen J, Yao TD, Joswia DR, Wang NL, Wu GJ, Wang M, Zhao HB, Yang W, Liu XQ, He JQ (2009) Black soot and the survival of Tibetan glaciers. Proc Natl Acad Sci 106(52):22114-22118

Yang XM, Li ZX, Feng Q, He YQ, An WL, Zhang W, Cao WH, Yu TF, Wang YM, Theakstone WH (2012) The decreasing wind speed in southwestern China during 1969-2009, and possible causes. Quat Int 263:71-84

Yang K, Wu H, Qin J, Lin CG, Tang WJ, Chen YY (2014) Recent climate changes over the Tibetan Plateau and their impacts on energy and water cycle: A review. Glob Planet Change 112:79-91

Yao TD (2008) Map of glaciers and lakes on the Tibetan Plateau and the surroundings. Xi' an Cartographic Publishing House, Xi'an

Yao TD, Thompson L, Yang W, Yu WY, Gao Y, Guo XJ, Yang XX, Duan KQ, Zhao HB, Xu BQ, Pu JC, Lu AX, Xiang Y, Kattel DB, Joswiak D (2012) Different glacier status with atmospheric circulations in Tibetan Plateau and surroundings. Nat Clim Change 2(9):663-667

Ye QH, Kang SC, Chen F, Wang JH (2006) Monitoring glacier variations on Geladandong mountain, central Tibetan Plateau, from 1969 to 2002 using remote-sensing and GIS technologies. J Glaciol 52(179):537-545

You QL, Fraedrich K, Min JZ, Kang SC, Zhu XH, Pepine N, Zhanga L (2014) Observed surface wind speed in the Tibetan Plateau since 1980 and its physical causes. Int J Climatol 34:1873-1882

Zeng L, Yang TB, Tian HZ (2013) Response of glacier variations in the eastern Pamirs plateau to climate change, during the last 40 years. J Arid Land Resour Environ 27(5):144-150

Zhang YS, Yao TD, Pu JC (1996) The characteristics of ablation on continental type glaciers in China. J Glacio \& Geocryo 18(2):147-154 (in Chinese with English abstract) 